\title{
Examining Social Responsibility Perceptions of Nurses: A Case Study of Istanbul Province
}

\author{
Gulay Tamer \\ Istanbul Gelisim Universty \\ E-posta: gtamer@gelisim.edu.tr \\ ORCID ID https://orcid.org/0000-0002-7897-1603
}

\begin{abstract}
By analyzing the development of social responsibility understanding, this work applies to the health sector with the participation of health workers in order to demonstrate the perception of corporate social responsibility. Within the scope of this study; to measure nurses' perceptions of social responsibility and to analyze the interaction between perception and demographic characteristics; Surveys including demographic statistics and indications of social responsibility were given to three hundred nurses working in public hospitals in the Istanbul city.

As a result, 250 out of 300 surveys were withdrawn and included in the study (the percentage of feedback was $83.3 \%$ ). According to the data obtained from the survey, the average score of the participants was 3.13 , thus the perception of corporate social responsibility in health care workers was found to be high. However, it is observed that the perceptions of social responsibility of nurses vary according to rank, gender and education.
\end{abstract}

Key words: Social Responsibility, Nurse, Health worker, corporate social responsibility

\section{Special Issue of Health Sciences}

DOI: $10.7176 / J S T R / 6-03-24$

\section{Hemşirelerin Sosyal Sorumluluk Algılarının İncelenmesi: İstanbul İli Örneği}

Bu çalışma; kurumsal sosyal sorumluluk algısını göstermek için sağlık çalışanlarının katılımıyla, sosyal sorumluluk anlayışının gelişimini analiz ederek, sağlık sektörüne uygulanmıştır. Çalışma kapsamında; İstanbul ilinde devlet hastanelerinde çalışan üç yüz hemşireye demografik istatistikler ve sosyal sorumluluk endikasyonlarını içeren anketler verilerek hemşirelerin sosyal sorumluluk algılarını ölçmek ve algı ile demografik özellikler arasındaki etkileşimi analiz etmek yer almaktadır. Sonuç olarak, 300 anketten 250'si çekilip ve çalıșmaya dahil edilmiștir (geri bildirim yüzdesi \%83,3'tür). Anketten elde edilen verilere göre, katılımcıların ortalama puanları 3,13 olup, sağlık çalışanlarında kurumsal sosyal sorumluluk algısı yüksek bulunmuştur. Ancak, hemşirelerin sosyal sorumluluk algılarının rütbe, cinsiyet ve eğitime göre değiştiği görülmektedir.

Anahtar kelimeler: Sosyal Sorumluluk, Hemşire, Sağlık çalışanı, kurumsal sosyal sorumluluk

\section{Introduction}

In the modern world, it is seen that the necessity for organizations to be sensitive to social issues is inevitable, aside from doing profit-oriented work. Private sector and public sector organizations carry out social responsibility activities through social projects. All these social responsibility activities carried out by the organizations are beneficial for the institutions themselves as well as the society. In addition to providing a positive image, the institutions have the opportunity to find themselves at the top of the competition in the competitive environment by responding to the expectations of the society. The subject 
of this paper has been selected in order to examine the development of the concept of social responsibility, the importance of which has been better understood by the organizations lately, and in order to exemplify the corporate social responsibility (CSR) concept in the public sector with a research in the field of health. The aim of the study is to identify the perspectives of health professionals on the issue of corporate social responsibility and to identify how this perspective interacts with gender and age. In our country, the health institutions, which have come a long way in improving patients' and employees' rights, quality service delivery, and patient satisfaction, have the opportunity to gain a positive image from the public through CSR activities. In the light of all these evaluations, it is considered that the approach of nurses working in health institutions to CSR practices is very important.

The scope of the research consists of health workers working full time in the health institutions of the public sector in Istanbul province between February and March 2019. As a data collection tool, the survey method was used to determine the demographic characteristics and social responsibility perceptions of the participants. The results obtained from 250 nurses working in health institutions in Istanbul province were analyzed by using SPSS 20 program.

\section{Social Responsibility}

With the product variety created as a result of the developments in industrialization, the organizations are able to satisfy consumer expectations in the extremes and in the best way possible, thus improving the quality of life and welfare. However, aside from these positive effects, the contribution of organizations to the negative results such as excessive consumption, harm to human and environment health, and deep differences between social groups is an indisputable fact. As such, the elimination or reduction of these negative results emerges as a responsibility of the organizations. The responsibilities organizations take in benefit of the society are defined as "social responsibility" 1 . Social responsibility defines the responsibilities of the person or the organization to the community, aside from individual responsibilities. In other words, the basis of responsible behavior consists of organizations considering the interests of the social stakeholders and not only their own interests, dealing with the social problems as well as their profit-oriented activities. The important point here is that social responsibility is based on volunteerism.

Today, the concept of social responsibility has started to be used quite frequently. The transition of organizations from the profit-oriented activities to the activities in accordance with the expectations of the society can be given as the reason of this situation. Especially with the development of information technologies and media, customers have become more conscious and their expectations from companies have increased. All these changes have made social responsibility practices inevitable for companies. Social responsibility consists of 4 components that are in relation to each other and sorted in order of priority. The economic responsibility, which is at the lowest level of these components, states that the company should make profit, whereas the legal responsibility level states that they should carry out their activities in accordance with the law. The moral responsibility states that they should respect the ethical values of the society, and the highest level states that the company should contribute to internal and external stakeholders by carrying out voluntary activities ${ }^{2}$.

\section{Corporate Social Responsibility}

The concept of CSR has taken place in our country since the 1990s. It has brought a new perspective to business management practices and expectations of society from the organization by bringing concepts such as corporate citizenship, business ethics, stakeholder management, and sustainability together ${ }^{3}$. The concept of CSR, which has achieved a significant place in the business world over time, is a concept that should be defined through its economical, legal, ethical, and volunteerism dimensions; it includes the activities directed at all internal and external stakeholders and the investments that will provide benefit to the society as well as achieving profit for the organization itself ${ }^{1}$. When the change in the concept of Corporate Social Responsibility since its emergence in the USA and Europe is considered, this concept, which is a legal obligation in many countries, is still included in the scope of voluntary practices under the name of corporate communication in our country. The concept of CSR offers quite a wide range while shortly expressing the responsibilities of companies towards society. For many companies, these responsibilities include making investments in areas such as education, health, sports, and arts; for other companies, it may involve activities such as avoiding the use of raw materials that are harmful to the environment during production ${ }^{4}$. However, until a short time ago, the main purpose of the organizations was seen as making profit in our country, and no budget was allocated to social responsibility activities because they were not thought necessary. Today, the most important capital for the management of a company is the brand value and corporate reputation. 
Today, it is seen that especially the foundations owned by large family companies fulfill their responsibilities by strengthening social solidarity through philanthropic activities ${ }^{5}$. In Turkey, CSR activities did not show improvement due to the failure of making long-term plans and the unsuitable conditions for sustainable development. The transition to a free economy in 1980s and the stable economy especially in recent years have enabled organizations in Turkey to focus on the CSR issue ${ }^{\mathbf{1}}$. The emergence of the concept of CSR in our country has not been as result of pressures coming from stakeholders as it was in Europe and the USA. It has been understood that with the increasing importance of CSR applications around the world, Turkish companies should give importance to these practices in order to sustain their activities and to adapt to the EU.

\begin{abstract}
A Field Study on Identifying Corporate Social Responsibility Perception Levels of Nurses Working in Istanbul

The research gains importance as there are few studies on Corporate Social Responsibility perceptions of employees, which are internal stakeholders. Another importance of the study is that when it comes to Corporate Social Responsibility activities in Turkey, these activities cannot be carried out at the desired level, especially in the public sector. The importance of the answers given to the social responsibility scale in the second part of our questionnaire, considering that the health sector has a particular place in social responsibility, is that it will provide information on the attitudes of nurses working in health institutions as a part of the public sector towards Corporate Social Responsibility activities, and it will contribute to the literature. Finally, this research is important because it focuses on the Corporate Social Responsibility concept from the point of view of the employees and provides information to managers and health professionals.
\end{abstract}

\title{
Material and Methods
}

The questionnaire method was chosen as a data collection tool. The reason for this is that the survey method provides more economic and faster data collection than other methods. The questionnaire used in the study was the survey Gültekin used in (2003). The questionnaire consists of two sections. In the first part of the questionnaire, information was given about the questionnaire and the participants were asked to answer the questions of demographic information such as age, gender, level of education, and how many years they practiced nursing.

In the second part of the questionnaire, social responsibility scale developed by Gültekin was used to determine the CSR perception of nurses. The items in this section are on the five-point Likert scale and are categorized as "totally agree," "agree," "neither agree or disagree," "disagree," "totally disagree." The cronbach $\alpha$ value of the social responsibility questionnaire, which composed of 28 statements in total, was found to be 0.744 .

The survey, which was found to be reliable as a result of this test, consists of 14 positive and 14 negative statements. In positive statements, "totally agree" was given 5 points, "totally disagree" was given 1 point; in negative statements, "totally disagree" was given 5 points, and "totally agree" was given 1 point. To collect demographic information, close-ended questions were used. All questions are close-ended. Frequency (f) and percentage (\%) values of all variables were calculated. The reliability analysis was applied to the scale, which was prepared to measure the participants' perspectives on social responsibility. Kolmogrov Smirnov Test was applied to test the normality assumptions of the scale. Kruskal Wallis-H Test and Mann Whitney U Test were applied in comparative analyses. When differences were observed in the results of Kruskal Wallis-H Test, Mann Whitney U Test was applied in order to find out which groups caused the difference. The findings were evaluated at the $95 \%$ confidence interval and at the $5 \%$ significance level.

The population of the research consists of nurses working full time in health institutions in the province of Istanbul. In the research, the units where the nurses worked were visited by the researcher, 300 questionnaires were distributed to the employees, and they were collected back after a certain amount of time. The number of valid questionnaires returned was 250 (return rate $=83.3 \%$ ). Therefore, 250 nurses that accepted to participate in the research constitute the sample of the research.

One of the limitations of the study is that the proportion of male participants in the sample is less than that of women due to the fact that the nursing profession is dominated by women. Another limitation of the study is that the seniority level of the participants is low due to the fact that nurses with higher seniority level did not agree to participate in the survey. Since the research was conducted in Istanbul province, the results cannot be generalized, which is another limitation of the study. It was assumed that all the nurses participating in the research gave sincere and realistic answers to the statements in the questionnaire. 
$76 \%$ of the 250 participants included in the study were female and $24 \%$ were male. $45.60 \%$ of the participants were between 20 and 27 years of age, $22.80 \%$ between 28 and 35 years of age, $22.40 \%$ between 36 and 43 years of age, and $9.20 \%$ were 44 years and over.

When the education level of the participants is examined, it is seen that $24.40 \%$ of them have graduated from high school, $30 \%$ have graduated from vocational school, $36.40 \%$ have bachelor's degree, and $9.20 \%$ have graduated from master's degree programs.

When the seniority of the participants are examined, it is seen that $\% 19.20$ of them worked less than 1 year, \% 29.60 between 1 and 5 years, \% 15.60 between 6 and 10 years, \% 35.60 for more than 10 years.

\section{Results}

It was found that the nurses answered the "Improving the society and being sensitive to the environment provides a more lasting success to the organization" statement with "totally agree" at a rate of \%36.40 $(n=91)$. The high level of participation in this statement suggests that they think the organization should be sensitive to social problems and that it is important to act with environmental consciousness in order to achieve lasting success. The statement "Lasting success is possible with supporting economical success with the success in social responsibility" was answered with "totally agree" at a rate of $\% 32.00$ $(\mathrm{n}=80)$, being the second most positively answered question. The statement "A manager who is sensitive to the problems of the society will bring a more lasting success to the organization" was answered with "totally agree" at a rate of $\% 31.0(\mathrm{n}=79)$, being the third most positively answered question. The fact that the participants' approval of this statement shows that the success of the organization is highly dependent on achieving sustainability, manager's offering solutions to social problems rather than avoiding them, providing benefits to the society, and improving the society. The statement "Each organization can fulfill its own social responsibilities" was answered with "totally agree" at a rate of $\% 29.60(n=74)$. Therefore, this statement is the fourth most positively answered question. It is found that the participants agree that the size of the organization is not related to fulfilling social responsibilities, each organization can deal with social problems within its own limitations. The statement "Everything can be done for the benefit of the company without considering the results" was answered with "totally disagree" at a rate of $41.20 \%$ $(\mathrm{n}=103)$, with the highest rate of disagreement. The statement "Every path followed in order to achieve economic purpose is permissable" was answered with "totally disagree" at a rate of $32.80 \%(\mathrm{n}=82)$, with the second highest rate of disagreement. The statement "Organizations should only fulfill their social responsibilities for their own good" was answered with "totally disagree" at a rate of \%28.40 $(\mathrm{n}=71)$, with the third highest rate of disagreement.

Although it is known that organizations can sustain their existence with economic profitability, the idea that profit is not the only goal has gained importance with the development of the concept of social responsibility. The social responsibility activities they carry out have advantages such as providing a positive image to the organization and contributing to the profits in the long term. However, as stated in this statement, organizations should carry out social responsibility activities not only for their own benefit, but also for contributing to the improvement of the society in which they exist and serve. The statement "It is not necessary to improve the society and be sensitive to the environment for the success of the organization" was answered with "totally disagree" at a rate of $\% 27.20(\mathrm{n}=68)$. This disagreement is the highest fourth in the social responsibility scale.Cronbach's alpha value of 28 variables was calculated as 0.744. Accordingly, we can say that Social Responsibility Scale is quite reliable. According to this result, the participants do not perceive the questions at the same rate. According to the scale statistics, the average of 28 items was 87.86, the standard deviation was 9.99, and the variance was 99.84 . The results of the Mann Whitney U Test performed to determine whether the scores of the participants on the social responsibility scale differ according to the gender variable.

The results of the Mann Whitney U Test, which is performed in order to determine whether the scores of the participants in the scores on the social responsibility scale differ according to the gender variable, are shown in Table 1. 
Table 1. Significance Levels of Participants' Scores in Social Responsibility Scale According to Gender Variable

\begin{tabular}{|c|c|c|c|c|}
\hline According to Gender Variable & Female & Male & $\begin{array}{c}\text { Mann- } \\
\text { Whitney U }\end{array}$ & $\mathrm{p}$ \\
\hline $\begin{array}{l}\text { 1. Expenses incurred by social responsibility do not bring an additional } \\
\text { cost to the organization. }\end{array}$ & 2.95 & 3.17 & 5175.500 & 0,267 \\
\hline $\begin{array}{l}\text { 2. I am not in favor of supporting any activity that does not bring profit } \\
\text { to the organization in short term. }\end{array}$ & 2.34 & 2.62 & 5212.000 & 0,290 \\
\hline $\begin{array}{l}\text { 3. Rather than being an environmentally conscious company with } \\
\text { optimum profitability, } \\
\text { I prefer to be a company that provides maximum profitability. }\end{array}$ & 2.28 & 2.68 & 4586.500 & $0,017 *$ \\
\hline $\begin{array}{l}\text { 4. If the organization focuses on social issues that concern society, it will } \\
\text { fail to make profit, which is its main objective. }\end{array}$ & 2.35 & 2.83 & 4343.000 & $0,003 *$ \\
\hline $\begin{array}{l}\text { 5. Social responsibility is a duty which only large organizations can } \\
\text { fulfill. }\end{array}$ & 2.17 & 2.53 & 4764.000 & $0,040^{*}$ \\
\hline $\begin{array}{l}\text { 6. Spending on social responsibility will provide positive feedback to } \\
\text { the organization in the long term. }\end{array}$ & 3.98 & 4.02 & 5557.000 & 0,730 \\
\hline 7. Improving the society is the duty of the state, not the organization. & 2.53 & 2.88 & 4741.000 & $0,037 *$ \\
\hline $\begin{array}{l}\text { 8. Organizations should only fulfill social responsibility for their own } \\
\text { interests. }\end{array}$ & 1.96 & 2.17 & 5149.000 & 0,207 \\
\hline $\begin{array}{l}\text { 9. For the success of the business, it is not necessary to improve the } \\
\text { society and to be sensitive to the environment. }\end{array}$ & 1.95 & 2.40 & 4580.000 & $0,012 *$ \\
\hline 10. The sole purpose of the organization should be to maximize profits. & 2.05 & 2.47 & 4650.500 & $0,019^{*}$ \\
\hline $\begin{array}{l}\text { 11. Each company can fulfill its own social responsibility within its own } \\
\text { limitations. }\end{array}$ & 4.11 & 4.15 & 5658.000 & 0,921 \\
\hline $\begin{array}{l}\text { 12. Society considers being sensitive to environmental problems more } \\
\text { important than economic growth. }\end{array}$ & 3.29 & 3.60 & 4754.000 & $0,043 *$ \\
\hline $\begin{array}{l}\text { 13. Organizations should fulfill social responsibility as a } \\
\text { requirement of respect for social values. }\end{array}$ & 3.88 & 4.02 & 5085.500 & 0,150 \\
\hline $\begin{array}{l}\text { 14. Improving the community and being environmentally friendly give } \\
\text { the enterprise a more lasting success. }\end{array}$ & 4.16 & 4.32 & 5182.500 & 0,236 \\
\hline $\begin{array}{l}\text { 15. The community is more interested in eco-friendly products, albeit at } \\
\text { the expense of a little sacrifice and high price. }\end{array}$ & 3.29 & 3.62 & 4387.500 & $0,005^{*}$ \\
\hline $\begin{array}{l}\text { 16. A manager who is sensitive to the problems of the society will bring } \\
\text { a more lasting success to the company. }\end{array}$ & 4.09 & 4.25 & 5153.500 & 0,209 \\
\hline $\begin{array}{l}\text { 17. For the benefit of the company, everything can be done without } \\
\text { considering the consequences. }\end{array}$ & 2.01 & 2.30 & 5155.000 & 0,237 \\
\hline $\begin{array}{l}\text { 18. The image of a company sensitive to social issues is more positive } \\
\text { than the image of a company that is financially strong but insensitive to } \\
\text { social issues. }\end{array}$ & 3.73 & 3.75 & 5591.000 & 0,813 \\
\hline $\begin{array}{l}\text { 19. The idea of community-centered management will become } \\
\text { increasingly important. }\end{array}$ & 3.88 & 3.88 & 691.500 & 0,984 \\
\hline $\begin{array}{l}\text { 20. If the company makes enough profit, its image in society is not very } \\
\text { important. }\end{array}$ & 2.09 & 2.50 & 4536.000 & $0,009^{*}$ \\
\hline $\begin{array}{l}\text { 21. Every path followed in order to achieve economic purpose is } \\
\text { permissible. }\end{array}$ & 2.01 & 2.45 & 4420.000 & $0,006^{*}$ \\
\hline $\begin{array}{l}\text { 22. The moral values of society do not constitute a binding point for } \\
\text { organizations, the main objective of which is profit. }\end{array}$ & 2.64 & 2.83 & 5126.000 & 0,223 \\
\hline $\begin{array}{l}\text { 23. The society follows the sensitivity of organizations towards social } \\
\text { problems with increasing sensitivity. }\end{array}$ & 3.66 & 3.63 & 5606.000 & 0,829 \\
\hline $\begin{array}{l}\text { 24. Social assistance and investments provide a positive return to the } \\
\text { organization in the long term. }\end{array}$ & 3.85 & 4.00 & 5194.500 & 0,234 \\
\hline $\begin{array}{l}\text { 25. If any application of the company is contrary to the moral values } \\
\text { of the society, the practice should be abandoned, even if it is } \\
\text { profitable. }\end{array}$ & 3.85 & 3.85 & 5672.500 & 0,950 \\
\hline $\begin{array}{l}\text { 26. If an organization maximizes its profits in the short term, it is } \\
\text { successful. }\end{array}$ & 3.24 & 3.68 & 4292.000 & $0,003^{*}$ \\
\hline $\begin{array}{l}\text { 27. A successful organization is an organization that fulfills its social } \\
\text { responsibility and distributes its profitability over the long term. }\end{array}$ & 4.08 & 4.13 & 5379.000 & 0,465 \\
\hline $\begin{array}{l}\text { 28. Permanent success is possible with supporting economical success } \\
\text { with the success in social responsibility. }\end{array}$ & 4.03 & 4.05 & 5641.500 & 0,896 \\
\hline
\end{tabular}
$* \mathrm{p}<0.05$

H1: The social responsibility perception of the participants varies according to their gender. 
As a result of Mann Whitney U Test, the difference between the points for determining social responsibility awareness and gender rankings were found to be statistically significant ( $\mathrm{p}<0.0010 .05)$. According to the findings, it is seen that male participants have higher social responsibility perceptions than female participants. According to male participants, companies need to be socially responsible, more sensitive to the environment, and sensitive to the problems of the society. It is clear that women are more distant from this idea than men. Female participants think that company interests are more important than behaviors requiring social responsibility.

Table 2. Mann Whitney U Test Results to determine whether the Points the Participants gave to the Social Responsibility Scale Differ according to the Gender Variable

\begin{tabular}{lllllll}
\hline Dimension & Variable & Groups & N & Ranking & $\begin{array}{l}\text { Mann } \\
\text { Whitney-U }\end{array}$ & P \\
\hline $\begin{array}{l}\text { Social Responsibility } \\
\text { Scale Score }\end{array}$ & Gender & Woman & 190 & 113.94 & 3504.5 & $<0.001$ \\
& & & & & & \\
\hline
\end{tabular}

The results of the Kruskal Wallis H Test performed to determine whether the scores of the participants on the scores on the social responsibility scale differ according to the age variable can be seen in Table 3. 
Table 3. Significance Levels of Participants' Scores in Social Responsibility Scale According to Age Variable

\begin{tabular}{|c|c|c|c|c|c|c|}
\hline By Age Variable & $20-27$ & $28-35$ & $36-43$ & $44+$ & $\chi^{2}$ & p \\
\hline $\begin{array}{l}\text { 1. Expenses incurred by social responsibility do not bring an additional } \\
\text { cost to the organization. }\end{array}$ & 2.79 & 2.96 & 3.50 & 2.96 & 11.298 & $0,010^{*}$ \\
\hline $\begin{array}{l}\text { 2. I am not in favor of supporting any activity that does not bring profit to } \\
\text { the organization in short term. }\end{array}$ & 2.53 & 2.26 & 2.25 & 2.57 & 2.773 & 0,428 \\
\hline $\begin{array}{l}\text { 3. I prefer to be a company that has maximum profitability rather than } \\
\text { being a company that improves the society and that is environmentally } \\
\text { sensitive with optimum profitability. }\end{array}$ & 2.57 & 2.32 & 2.13 & 2.17 & 5.525 & 0,137 \\
\hline $\begin{array}{l}\text { 4. If the organization focuses on social issues that concern society, it will } \\
\text { fail to make profit, which is its main objective. } \\
\text { fails to provide. }\end{array}$ & 2.52 & 2.30 & 2.46 & 2.61 & 1.190 & 0,756 \\
\hline 5. Social responsibility is a duty which only large organizations can fulfill. & 2.36 & 2.07 & 2.18 & 2.43 & 1.722 & 0,632 \\
\hline $\begin{array}{l}\text { 6. Spending on social responsibility will provide positive feedback to the } \\
\text { organization in the long term. }\end{array}$ & 4.16 & 3.98 & 3.88 & 3.43 & 16.191 & $0,001 *$ \\
\hline 7. Improving the society is the duty of the state, not the organization. & 2.68 & 2.61 & 2.54 & 2.48 & 0.845 & 0,839 \\
\hline $\begin{array}{l}\text { 8. Organizations should only fulfill social responsibility for their own } \\
\text { interests. }\end{array}$ & 2.00 & 1.88 & 2.02 & 2.35 & 4.109 & 0,250 \\
\hline $\begin{array}{l}\text { 9. For the success of the business, it is not necessary to improve the society } \\
\text { and to be sensitive to the environment. }\end{array}$ & 1.94 & 2.09 & 2.30 & 1.96 & 5.868 & 0,118 \\
\hline 10. The sole purpose of the organization should be to maximize profits. & 2.09 & 2.14 & 2.18 & 2.39 & 1.884 & 0,597 \\
\hline $\begin{array}{l}\text { 11. Each company can fulfill its own social responsibility within its own } \\
\text { limitations. }\end{array}$ & 4.09 & 4.21 & 4.27 & 3.70 & 7.179 & 0,066 \\
\hline $\begin{array}{l}\text { 12. Society considers being sensitive to environmental problems more } \\
\text { important than economic growth. }\end{array}$ & 3.52 & 3.07 & 3.38 & 3.356 & 6.787 & 0,079 \\
\hline $\begin{array}{l}\text { 13. Organizations should fulfill social responsibility as a requirement of } \\
\text { respect for social values. }\end{array}$ & 3.89 & 3.89 & 3.93 & 4.04 & 1.304 & 0,728 \\
\hline $\begin{array}{l}\text { 14. Improving the community and being environmentally friendly give the } \\
\text { enterprise a more lasting success. }\end{array}$ & 4.26 & 4.14 & 4.16 & 4.09 & 4.763 & 0,190 \\
\hline $\begin{array}{l}\text { 15. The community is more interested in eco-friendly products, albeit at the } \\
\text { expense of a little sacrifice and high price. }\end{array}$ & 3.49 & 2.95 & 3.48 & 3.57 & 13.462 & $0,004 *$ \\
\hline $\begin{array}{l}\text { 16. A manager who is sensitive to the problems of the society will bring a } \\
\text { more lasting success to the company. }\end{array}$ & 4.21 & 3.93 & 4.20 & 4.09 & 10.544 & $0,014^{*}$ \\
\hline $\begin{array}{l}\text { 17. For the benefit of the company, everything can be done without } \\
\text { considering the consequences. }\end{array}$ & 2.05 & 1.96 & 2.20 & 2.22 & 2.083 & 0,555 \\
\hline $\begin{array}{l}\text { 18. The image of a company sensitive to social issues is more positive } \\
\text { than the image of a company that is financially strong but insensitive to } \\
\text { social issues. }\end{array}$ & 3.76 & 3.67 & 3.93 & 3.30 & 7.185 & 0,066 \\
\hline $\begin{array}{l}\text { 19. The idea of community-centered management will become increasingly } \\
\text { important. }\end{array}$ & 3.85 & 3.91 & 4.00 & $3.70=$ & 3.106 & 0,376 \\
\hline $\begin{array}{l}\text { 20. If the company makes enough profit, its image in society is not very } \\
\text { important. }\end{array}$ & 2.31 & 2.04 & 2.18 & 2.04 & 2.970 & 0,396 \\
\hline $\begin{array}{l}\text { 21. Every path followed in order to achieve economic purpose is } \\
\text { permissible. }\end{array}$ & 2.31 & 1.77 & 2.13 & 2.00 & 10.644 & $0,014 *$ \\
\hline $\begin{array}{l}\text { 22. The moral values of society do not constitute a binding point for } \\
\text { organizations, the main objective of which is profit. }\end{array}$ & 2.74 & 2.67 & 2.77 & 2.26 & 3.375 & 0,337 \\
\hline $\begin{array}{l}\text { 23. The society follows the sensitivity of organizations towards social } \\
\text { problems with increasing sensitivity. }\end{array}$ & 3.64 & 3.75 & 3.70 & 3.35 & 2.864 & 0,413 \\
\hline $\begin{array}{l}\text { 24. Social assistance and investments provide a positive return to the } \\
\text { organization in the long term. }\end{array}$ & 3.89 & 3.88 & 3.91 & 3.87 & 0.939 & 0,816 \\
\hline $\begin{array}{l}\text { 25. If any application of the company is contrary to the moral values of the } \\
\text { society, the practice should be abandoned, even if it is profitable. }\end{array}$ & 3.75 & 4.00 & 3.91 & 3.83 & 1.757 & 0,624 \\
\hline $\begin{array}{l}\text { 26. If an organization maximizes its profits in the short term, it is } \\
\text { successful. }\end{array}$ & 3.54 & 3.23 & 3.25 & 2.96 & 9.132 & 0,028 \\
\hline $\begin{array}{l}\text { 27. A successful organization is an organization that fulfills its social } \\
\text { responsibility and distributes its profitability over the long term. }\end{array}$ & 4.16 & 4.16 & 4.00 & $3.87=$ & 3.061 & 0,382 \\
\hline $\begin{array}{l}\text { 28. Permanent success is possible with supporting economical success } \\
\text { the success in social responsibility. }\end{array}$ & 4.00 & 4.14 & 4.05 & 3.87 & 2.159 & 0,540 \\
\hline
\end{tabular}

\section{*p< $<0.05$}

H2: The social responsibility of the participants varies according to their age. 


\begin{tabular}{llllllll}
\hline Score & Variable & Groups & N & ranking & $\mathbf{x}^{\mathbf{2}}$ & sd & $\mathbf{p}$ \\
\hline Social Responsibility Scale & Age & $20-27$ & 114 & 134.54 & 7.330 & 3 & 0.062 \\
Score & & & & & & & \\
& & $28-35$ & 57 & 104.7 & & & \\
& & $36-43$ & 56 & 119.50 & & & \\
& & 44 and & 23 & 131.38 & & & \\
& & & & & \\
\hline
\end{tabular}

As a result of the Kruskall Wallis-H Test, the difference between the social responsibility awareness of the participants and the averages of age variables was not statistically significant $(x 2=7.330 ; p>0.05)$.

\section{Conclusion}

As a result of the comparative analysis, the gender of the participants changed their perception of social responsibility, and it was observed that the age did not cause a significant difference in the perception of social responsibility. It is seen that the social responsibility awareness of male participants is higher than that of female participants. We can say that the perspectives of male participants on social responsibility are more positive. According to men, the organization must fulfill its social responsibilities, be more sensitive to the environment, and be sensitive to the problems of the society.

As a result of the correct implementation of social responsibility activities, the organization will be able to achieve a positive return in the long term. It is clear that women are more distant from this idea than men. Female participants think that company interests are more important than behaviors requiring social responsibility. In other words, according to women, the organization should be engaged in activities that will bring profit rather than social activities. In our study, it was found out that the age of the employees did not make any difference on their perceptions of social responsibility, and that the views of the employees of all ages were close to each other.

\section{References}

1. Ceritoğlu. Kurumsal Sosyal Sorumluluk ve İşletmelerin Çevre Bilinci Eksenindeki Uygulamalarının Tüketici Satın Alma Davranışı ve Kurum İmajı Algısına Etkisi, İstanbul: Yalın Yayınc1lı; 2011.

2. Carroll, Archie. (1991). The Pyramid of Corporate Social Responsibility: Toward the Moral Management of Organizational Stakeholders. Business Horizons. 34. 39-48. 10.1016/00076813(91)90005-G.

3. Deren Van HetHof. Kurumsal Sosyal Sorumluluk Kavramlar, Uygulama ve Örnekler, Antalya:Nobel Yayıncılık; 2015.

4. Akansel. Türk Futbolunun Kurumsal Sosyal Sorumluluk Algıs1, [unpublished master's thesis]. İstanbul, Türkiye; Bahçeşehir Üniversitesi, Sosyal Bilimler Üniversitesi, Spor Yönetimi Yüksek Lisans Programi; 2011.

5. Ersöz. Kurumsal Toplumsal Sorumluluk: Aydın Organize Sanayi Bölgesinde Üretim İşletmeleri Örneği, [unpublished PhD thesis]. Aydın, Türkiye: Adnan Menderes Üniversitesi, Sosyal Bilimler Enstitüsü, İşletme Anabilim Dalı; 2014

6. Aslantaş Ateş and Senal, 2012. "Kurumsal Sosyal Sorumluluk Kapsamında Muhasebenin Sosyal Sorumluluğu", Süleyman Demirel Üniversitesi'nde Bir Araştırma, Çukuova Üniversitesi İİBF Dergisi, Volume 16, Issue 1, June 2012, 71-85

7. Aydemir, and Ateş. "Küçük Sanayi Sitelerinde Sosyal Sorumluluk Olgusu: Bilecik Küçük Sanayi Sitesi Örneği”. Dumlupınar Üniversitesi Sosyal Bilimler Dergisi. 2011; Issue 30, 169-180. August 2011.

8. Bakioğlu and Akkaya. "Okul Yöneticilerinin Sosyal Sorumluluğu Algılamalarının İncelenmesi”, Marmara Üniversitesi Atatürk Eğitim Fakültesi Eğitim Bilimleri Dergisi, 2013; Issue 37, 56-67 
2013.

9. Değirmen C. Kurumsal Pazarlama ve Sosyal Sorumluluk, İzmir: Nobel Yayıncılık; 2010

10. Gültekin. İşletmelerin Sosyal Sorumluluğunun Rolü ve GAP Bölgesi Yöneticilerinin Sosyal Sorumluluk Anlayışlarını Belirlemeye Yönelik Bir Araştırma, [unpublished master's thesis]. İstanbul, Türkiye: Marmara Üniversitesi, Sosyal Bilimler Enstitüsü; 2003.

11. Gürel Boran T. Türkiye'den Uygulama Örnekleriyle Kurumsal Sosyal Sorumluluk, İstanbul: Beta Yayınevi. 2015.

12. Kaya."Demografik Özelliklerin Kurumsal Sosyal Sorumluluk Algılaması Üzerindeki Rolü: Bandırma Yerelinde Bir Araştırma”, Balıkesir Üniversitesi Sosyal Bilimler Enstitüsü Dergisi, 2008; Volume 11, Issue 20, December, 96-110, 2008.

13. Köroğlu and Ersöz. "Muhasebe Meslek Mensuplarının Bakış Açılarından Kurumsal Sosyal Sorumluluk Muhasebe İlişkisi”, Journal of Accounting, Finance and Auditing Studies, 2015; Volume 1, Issue 3, 123-153.

14. Özdemir. Çalışanların Kurumsal Sosyal Sorumluluk Algılamalarının Örgütsel Özdeşleşme, Örgütsel Bağlılık ve İş Tatminine Etkisi: Opet Çalışanlarına Yönelik Bir Uygulama, [unpublished PhD thesis]. İstanbul, Türkiye: Marmara Üniversitesi, Sosyal Bilimler Enstitüsü; 2007.

15. Özgen. "Kurumsal Sosyal Sorumluluk Kavramı ve Çalışan Memnuniyetine Etkisi”, Dicle Üniversitesi Ziya Gökalp Eğitim Fakültesi Dergisi, 2007; Issue 8, pp. 1-6. 